\title{
Når kursene tar overhånd
}

\author{
Dilla på kurs eller kurs hos Lappedilla? Det finnes kurs om alt mulig. Du kan ta bølgekurs for kajakkpadlere \\ eller kurs i epidemiologi. Kursmanien går i bølger, og i en periode var den nærmest epidemisk.
}

| 1970-årene ble det mer og mer populært å gå på kurs. Det gjaldt innen alle tenkelige områder, både faglige og for fritidsinteresser. Slike kurs kunne være direkte kompetansegivende og viktige for å utdanne seg videre eller for å oppdatere kunnskapene. Imidlertid var ikke dette alltid tilfellet, og enkelte ganger kunne det være tvil om hva som var formålet med kurset. Det spilte imidlertid ikke noen særlig rolle. Det viktigste var at man gikk på kurs.

I egenskap av professor i patologi ble jeg selv utsatt for mange ulike kurs, både som lærer og som mottaker av kunnskapen. Da oppdaget jeg at kurs gjerne gikk i bølger, slik at ethvert kurs førte til ikke bare ett, men gjerne flere nye kurs. Til slutt var en så stor del av den norske befolkning på kurs at det virket som en epidemi. Mens byråkratitis i Olav Hilmar Iversens fremstilling syntes å skyldes et eget virus, så denne kursmanien ut til å utbres gjennom direkte psykisk smitte. Slike bølger av bestemte former for atferd har vært kjent gjennom tidene, alt fra fredelige sysler som ekstrem jogging og overdreven slanking med og uten lavkarbo, til spillegalskap og ildspåsettelse. På den bakgrunnen skrev jeg en origi- nalartikkel som ble publisert i Nordisk Medicin. Her ble for første gang lidelsen cursomania epidemica beskrevet.

Reaksjonene uteble ikke. Jeg fikk tallrike takkebrev fra lesere over hele landet og dessuten blomsterbuketter fra flere lærere som hadde lidd av sykdommen. I det hele tatt så lærerne ut til å være dem som var hardest rammet av kursmani, og artikkelen ble gjentrykt i en rekke fagblad, inklusive Norsk Skoleblad. I dag ser kursmanien ut til å ha gitt seg, men hvem vet om den ikke blusser opp igjen en vakker dag.

\section{Ole Didrik Lærum}

ole.laerum@gades.uib.no

Ole Didrik Lærum (f. 1940) er professor (adj.) ved Københavns Universitet og professor emeritus i patologi ved Gades institutt, Universitetet i Bergen.

\section{Cursomania epidemica: et smittsomt psykisk syndrom}

\author{
Smittsomme psykiske lidelser er meget sjeldne. Cursomania epidemica er et eksempel på en slik lidelse \\ med økende utbredning. Uten behandling kan lidelsen ha alvorlige følger. Ikke minst fordi sykdommen fullt \\ utviklet er meget smittsom, må man gripe inn i tide. Det er å anta at det virus som sannsynligvis forårsaker \\ sykdommen finnes så å si overalt. Sykdommens forløp, behandlingsmuligheter og prognose beskrives \\ i denne oversikt.
}

Ole Didrik Lærum Lærum OD. Cursomania epidemica - et smittsomt psykisk syndrom. Nord Med 1979; 94: 105-7.

Figurene er laget av Inge Morild, Avdeling for patologi, Haukeland universitetssykehus.

\begin{abstract}
Den bølge av kurser innen alle tenkelige fagkretser som har herjet i de siste årene har ikke gått sporløst hen. Under mottoet: «Hele folket på kurs» har mektige krefter gått inn for at alle skal utdannes enten de vil eller ei, og den jevne borgers kursfrekvens har steget eksponensielt. Dette har disponert for et egenartet psykisk syndrom som en viss prosent av kursgjengerne utvikler. Da det er en smittsom lidelse som uten behandling kan ha alvorlige følger, vil jeg her gjøre oppmerksom på den. Behandlingen er forholdsvis enkel hvis ikke syndromet får utvikle seg for langt.
\end{abstract}

Smittsomme psykiske lidelser er ellers meget sjeldne. En av dem er den såkalte kuru, lattersyke, som er en virusbetinget lidelse hos visse innfødte stammer på New Guinea. Det er meget sannsynlig at også cursomania epidemica skyldes et virus, idet den forløper epidemisk. Dette virus er foreløbig ikke kjent. Det synes ikke å ha noen sammenheng med forkjølelse eller influensavirus. Alvoret i sykdommen tyder på at den heller ikke har noe med lattersykeviruset å gjøre. Sterke predisponerende faktorer er imidlertid nødvendige for at noen skal utvikle syndromet i full blomst.
Et beslektet syndrom, byråkratitis (Iversen; Pulsen (Rikshosp.) 4: 10-14, 1977) har sannsynligvis liknende virusetiologi.

\section{Patogenese og symptomatologi} Erfaringene med de senere års kurs- og etterutdanningsvirksomhet har etterhvert utkrystallisert noen eiendommelige tendenser. Det viser seg å være liten sammenheng mellom utdanningsbehov og kursfrekvens. De som fortrinnsvis går på kurser er de som allerede er utdannet og som i tillegg har gått på en rekke tidligere kurser. Med andre ord ser det ut til at ethvert kurs dispo- 
nerer for et nytt kurs. Dernest viser det seg at hos mange slike deltakere er det liten eller ingen faglig sammenheng mellom kursene de går på. Hos enkelte har dette gått så vidt at man kan tale om en egen lovmessighet - nemlig kursenes gjensidig manglende relasjonstendens.

Hos noen deltakere har frekvensen nådd et avansert stadium: De går på mange slags kurser samtidig. I tillegg går de gjerne et kurse-kurs, det vil si et videregående kurs i kursgåing - hvordan bli en god kursgåer. På dette kan man bygge et kursledelseskurs for også å trekke andre med seg i løpet. Noen utvikler en så høy kursfrekvens at man kan tale om en «mani» på linje med kleptomani og andre tvangsneuroser. Når dette syndromet er fullt utviklet er det meget smittsomt, idet man gjerne ser hele grupper av mennesker som samtidig er angrepet. Alt etter symptomatologien kan man dele pasientene inn i flere undergrupper:

1. Lystkursere, også kalt kosekursere (figur 1). Disse synes det er så vanvittig hyggelig med kurs, fortrinnvis de som finner sted på høyfjellshoteller og i andre behagelige omgivelser. De pleier ikke å høre etter hva som blir sagt og kommer således unna all tvangsforing med ubegrensede kunnskapsmengder uten å bli psykisk altfor påfallende. For dem er røyke- og spisepausene det viktigste, mens det faglige innhold er totalt irrelevant. Hotell med svømmebasseng og fulle skjenkerettigheter har størst tilstrømning av lystkursere.

Hos lystkursere kan man se ganske rask progresjon av sykdommen, men i motsetning til nedennevnte to kategorier har den alltid et godartet forløp.

2. Utdanningsmanomane. Hos disse er det ingen grense for hva de skaffer seg av utdanning, uansett hva det går ut på. Det eneste målet her i livet er å drive og utdanne seg, og deres almenne leveregel er: «Den som tror han er ferdig utdannet er ikke utdannet - han er ferdig.» Dette er kanskje den største gruppen, og med fullt utviklet sykdomsbilde kan de gjennomgå et uhorvelig stort utdanningstilbud i løpet av forholdsvis kort tid. Det pleier ikke å være noen som helst faglig relasjon mellem de enkelte kurser og andre utdanningstilbud pasienten gjennomgår. Ofte bærer de sterkt psykisk preg av sin sykdom og deres dagligtale er gjerne ekstremt kursorientert (figur 2).

\section{Tvangskursere. Her har sykdommen et} sterkt tvangspreget forløp og de angrepne plages gjerne av angst når de ikke går på kurser (figur 3). For dem er ventedagene mellom kursene en stor påkjenning og ledsages ofte av hypertensjon og andre stressfenomener. Likeledes kan de få angstanfall når det er røyke- eller spisepause på kurset. Angsten letner så snart de løper inn igjen i forelesningssalen.

\section{Differensialdiagnose}

For å kunne si med sikkerhet at en pasient lider av epidemisk kursmani, må man først utelukke andre psykiske lidelser med liknende symptomer. Da har symptomene gjerne vært tilstede før pasienten begynte å gå på kurs. Lattersyke skulle ikke by på noe differensialdiagnostisk problem, selv ikke hos lystkursene, enda de også kan ha sterkt løftet stemning. Som nevnt begrenser den euforiske perioden seg til kursdagene, fortrinnsvis pausene.

Derimot kan det være vanskelig å avgjøre om en kursmaniker tilhører kategori 1, 2 eller 3. Her er kursbeviset av stor differensialdiagnostisk betydning. For gruppe $2 \mathrm{og}$ 3 er utdelingen av kursbevis den største tilfredsstillelse, nærmest å sidestille med en åndelig orgasme. Denne etterfølges av en sekundær depresjonsperiode inntil de får startet på et nytt kurs.

For lystkurserne derimot er utdelingen av kursbeviset et sorgens kapitel. Depresjon og angstfenomener melder seg fortrinnsvis rett etter siste kurstime.

\section{Forløp og bivirkninger}

Stort sett har epidemisk kursmani et godartet forløp. Mange oppnår spontan helbredelse og kommer etterhvert på rett kurs. Hos andre derimot kan sykdommen progrediere raskt og medføre en rekke bivirkninger. Hvis pasienten kommer opp i et antall på over 20 samtidig forløpende kurs, kan han bare reddes av raskt innsettende behandling.

Ser man bort fra selve grunnlidelsen, er bivirkningene forholdsvis god-artede. Hyppigst ser man hardnakket obstipasjon på grunn av all sittingen. Av samme grunn kan de plages av meteorisme på grunn av hindret flatusavgang i de mange undervisningstimer (figur 4). Plattfothet på grunn av at pasienten tasser fra kurs til kurs er heller ikke uvanlig.

\section{Behandling}

Når det gjelder en pasient med fullt utviklet syndrom frarådes det å gå til drastisk behandling. Plutselig kursstopp kan gi alvorlige psykiske abstinenssymptomer, fortrinnsvis i form av angst og depresjon. I stedet anbefales det å sette pasienten på et avvennende kurs med desensibilisering.

Siden sykdommen forløper epidemisk egner den seg godt til gruppe-terapi. Selv om sykdommen er smittsom er det ikke nødvendig med karantene, idet den bare angriper predisponerte individer, det vil si etablerte kursgjengere. I hvilken grad man

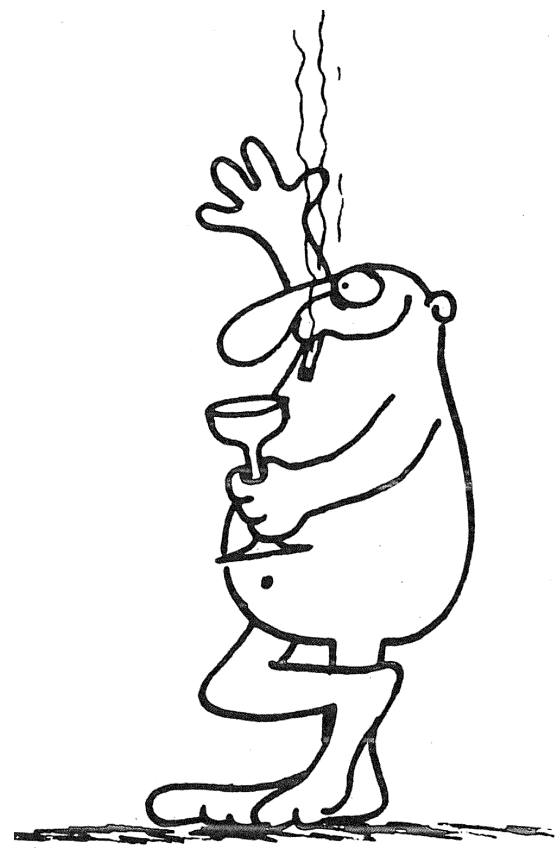

Figur 1. Lystkurser.

skal gi medikamentell behandling avhenger av det individuelle tilfelle. Milde avføringsmidler kan ha god effekt hos tvangskurseren.

Særlig vanskelig å behandle er den såkalte status cursaticus. Da har all kursløpingen medført en total overbelastning av de psykiske funksjoner og spesielt læreevnen. Den uhorvelige mengde kunnskapsdata som er banket inn i pasienten kan medføre en akutt forvirringstilstand. Det kalles med et gammelt norsk ord «vetsprengd» (figur 5).

\section{Diskusjon}

I denne lille oversikten har jeg ikke brydd meg med å beskrive noen enkeltkasus inngående. Kursvirksomhet er i dag så hyppig at de fleste vil ha sett karakteristiske tilfelle i sin nærmeste familie eller bekjentskapskrets. Det er å anta at det virus som forårsaker sykdommen finnes så å si overalt. Derfor ligger muligheten for epidemisk forløp til rette ethvert sted hvor det drives utstrakt kursvirksomhet.

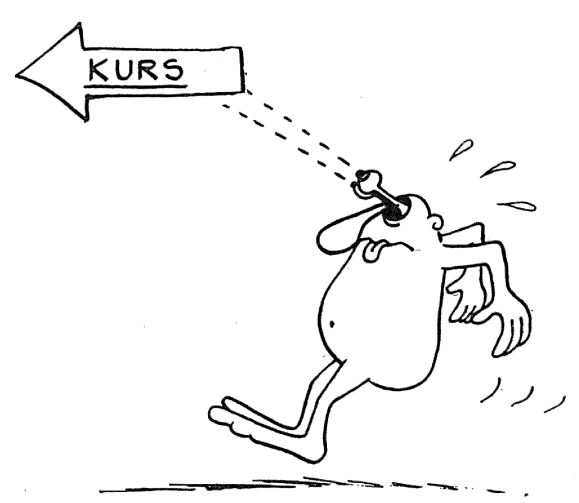

Figur 2. Utdanningsmanoman. 


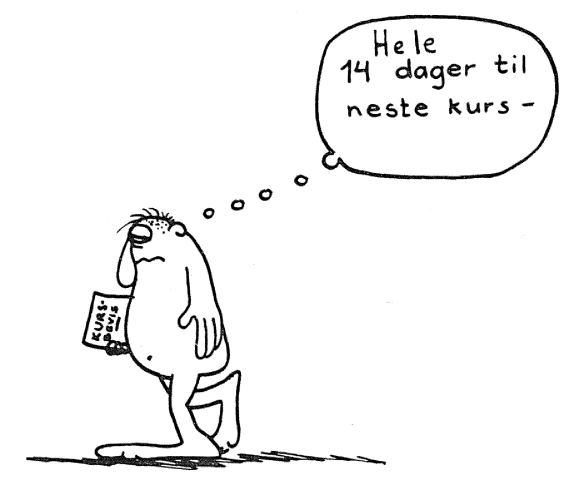

Figur 3. Tvangskurser.

De siste års oppbygging av systematisk kursvirksomhet innen forskjellige fagkretser representerer et verdifullt og viktig utdanningstilbud for store befolkningskategorier, ikke minst innen legestanden. Desto mer sørgelig er det at et slikt verdifullt tiltak skal ha bivirkninger som nærmest går på helsa løs. Enda verre er det at vi bare har symptomatisk behandling å tilby den hardt

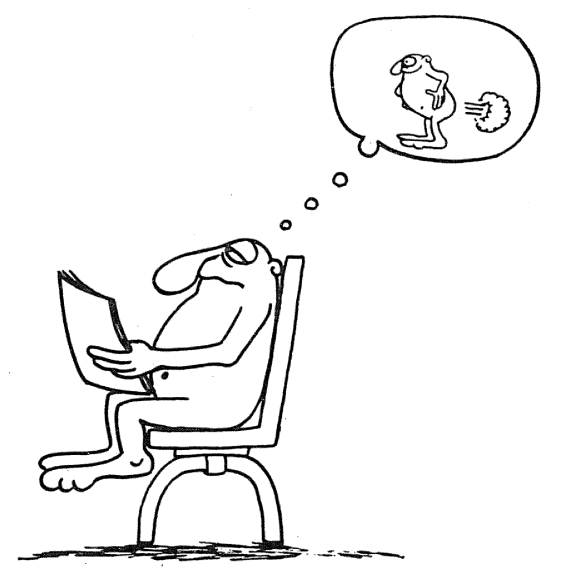

Figur 4. Kursmaniker med moderate bivirkninger. angrepne pasient. Derfor er det viktig å huske på ordtaket som sier at «profylakse er den beste form for forebyggelse».

Vi skal så se nærmere på et par faktorer som bidrar til at kursvirksomhet overdrives. Som bekjent avsluttes det alltid med en diskusjon, og her er det kursmanikerne avslører seg. De manifesterer seg ved en ordrik, men samtidig særdeles begrepsfattig språkbruk, nærmest en slags stereolali: de samme ordene går om igjen og om igjen, og de sammenstilles gjerne etter tilfeldighetens lov. Eksempler: strukturert, strukturnivå, adekvat, på sikt, i snitt, deltagerstyrt, måleller problemorientert, motivert, relatert, relevant, prosessevaluering, miljø og/eller ressursproblematikk, målsetting, osv.

Til slutt munner det ut i den såkalte kursevaluering hvor man ikke har den ringeste interesse av å vurdere selve kurset - nei det ville være å bruke ordet evaluering i sin korrekte og derfor i denne sammenheng totalt misforståtte betydning. Evalueringen går først ut på litt ros, eller på kursspråket: positiv og konstruktiv evalueringsutredning. Altså: kurset har vært av stor betydning, ikke bare på det foreliggende strukturnivå, men også på sikt; kurset har vist sin berettigelse og har vært relevant. Deretter gis det litt generell kritikk. Den bør helst være så generell at den kan tiltres også av dem som ikke har hørt etter hva som ble sagt på kurset. Konklusjon: Det bør arrangeres et nytt og - vel å merke - snarlig kurs. Alle er fornøyde, pakker kofferten og sees snart igjen.

\section{Konklusjon}

Kanskje burde vi, spesielt vi som tilhører kategorien helsepersonell, gå i bresjen og prøve å få et sunnere forhold til kunnskapstilegning. Vi må her ta med i betragtningen at den totale kunnskapsmengde i verden har

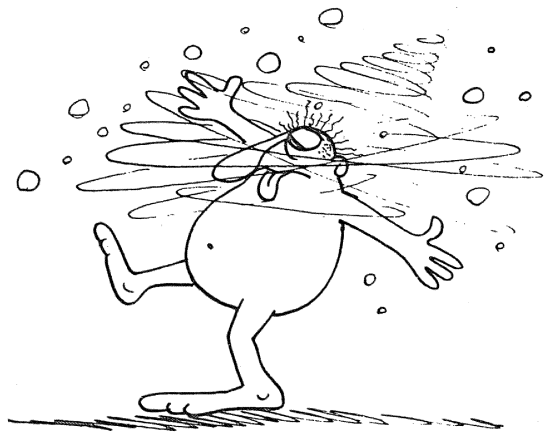

Figur 5. Status cursaticus («vetsprengd»).

blitt doblet hvert tiende år siden annen verdenskrig. Vi kan derfor snakke om en kunnskapseksplosjon som på mange måter er å sammenlikne med en miljøforurensning. Det er jo ikke sikkert at alle enkeltdata representerer noe framskritt. Derfor er det heller ikke sikkert at ethvert kurs representerer kunnskaper som er verd å tilegne seg. Tvert i mot er det viktigere enn noensinne å kunne selektere våre kunnskaper og holde vår tankeverden fri og ren for all unødvendig kunnskapsballast. Ellers kan det tenkes at kursaktiviteten både i fagforbundene og samfunnets interesse bringes til et ekstremt nivå der alle må delta. Kanskje trengs det fyldig helseerklæring både fra lege og psykolog utfylt på eget skjema $\mathrm{i}$ fire eksemplarer før en utkommandert kursdeltaker får slippe fri ...

OLE DIDRIK LÆERUM, dosent, dr med, Gades institutt, Avdeling for patologi, Universitetet i Bergen, N-5016 Haukeland sykehus. Figurene er laget av dr INGE MORILD ved samme avdeling.

Nordisk Medicin 94: 105-107, 1979. 